\title{
Validity of Restrictions on Employee Activities in Opposition to an Incumbent Union
}

Under the National Labor Relations Act, ${ }^{1}$ a union designated or selected by the majority of employees in a bargaining unit serves as the exclusive bargaining representative for all employees in the unit regardless of the union affiliation of any single employee. ${ }^{2}$ Generally, the bargaining representative retains this exclusive status until a majority of unit employees vote to decertify or replace ${ }^{3}$ the representative in an election conducted by the National Labor Relations Board (NLRB). Leaders of incumbent unions have employed various means to discourage employee activities in support of decertification or replacement. ${ }^{4}$

One frequently used tactic is for the union to negotiate a collective bargaining agreement that authorizes the employer to discharge or suspend unit employees who solicit union membership or distribute literature on company premises. ${ }^{5}$ The NLRB has held the adoption and enforcement of such provisions to be unfair labor practices on the part of

1 Ch. 372, \$§ I et seq., 49 Stat. 449 (1935), as amended 29 U.S.C. \$§ 151 et seq. (1970) [hereinafter cited as NLRA].

2 NLRA § 9(a), 29 U.S.C. § 159(a) (1970). This designation or selection may be through a Board certification election conducted according to the procedures of $\S 9$, or by employer recognition based on authorization cards or other independent evidence of majority status. NLRB v. Gissel Packing Co., 395 U.S. 575, 596-97 (1969).

3 The term "decertify" is generally used to refer to the removal of exclusive authority from the incumbent union in favor of either another bargaining representative or individual negotiations. For the sake of clarity, this comment frequently uses the term "replace" to refer to the former situation.

4 The National Labor Relations Board, hereinafter referred to as the NLRB or the Board, will conduct an election only in response to a petition filed by an employee or an employer that shows "reasonable cause to believe that a question of representation . . . exists . . . NLRA § 9(c)(1), 29 U.S.C. § I59(c)(1) (1970). Ordinarily the petitioner must provide evidence that 30 percent of the employees in the unit have authorized the election or representation by the replacing union. NLRB Statements of Procedure, Series 8, 29 C.F.R. $\S 101.18$ (a) (1973). As a result, a significant amount of antiunion campaigning generally occurs prior to the official scheduling of an election.

5 Such sanctions, although they may be imposed against proponents of both the incumbent and its rivals, in practice favor the incumbent because of the requirement of a petition showing support for an election. See note 4 supra. In addition, the incumbent usually has various advantages in reaching employees with its message, for example bulletin boards provided by the employer for incumbent union use, partisan union papers, union meetings, and notoriety resulting from its position of authority. See NLRB v. Mid-States Metal Prods. Co., 403 F.2d 702, 705 (5th Cir. 1968). 
both the union and the employer. The circuits have split over the validity of these provisions. ${ }^{\mathrm{B}}$

Other methods employed by unions to discourage activities in opposition to an incumbent include the fining and suspension or expulsion of members who support a rival union or engage in other "conduct unbecoming a union member," such as attempting to decertify the incumbent. Although the use of fines in this situation has been disapproved, ${ }^{7}$ neither the NLRB nor the courts have found the use of either suspension or expulsion to be an unfair labor practice. ${ }^{8}$

This comment will examine the present rules governing control of union member activities in this area, through collective bargaining agreements and through internal union discipline. It will be suggested that a no-solicitation provision in a collective bargaining agreement must be held to constitute an unfair labor practice, that union-imposed fines have been properly rejected and expulsion improperly allowed as means of intra-union discipline for such activities, and that suspension for the period immediately preceding an election is a permissible reaction to antiunion activities.

\section{Watvers of Solicitation AND Distribution Rights in Collective Bargaining Agreements}

\section{A. The Response of the Legal System}

It has generally been held to be an unfair labor practice under sections $8(a)(1)^{9}$ and $8(a)(3)^{10}$ of the NLRA for an employer unilaterally to promulgate or apply a rule disciplining employees for union solicitation during nonworking time or distribution of literature in nonworking areas of the plant. ${ }^{11}$ Although this rule was originally devel-

B See text and notes at notes 14-30 infra.

7 See text and notes at notes 61-75 infra.

8 See text and notes at notes $76-91$ infra.

O Section 8(a)(1), 29 U.S.C. § 158(a)(1) (1970), provides that it is an unfair labor practice for an employer "to interfere with, restrain, or coerce employees in the exercise of rights guaranteed in section 7." Section 7, 29 U.S.C. $\$ 157$ (1970), provides in part: "Employees shall have the right ... to bargain collectively through representatives of their own choosing, and to engage in other concerted activities ...."

10 Section 8(a)(3), 29 U.S.C. \& 158(a)(3) (1970), provides that it is an unfair labor practice for an employer "by discrimination in regard to hire or tenure of employment or any term or condition of employment to encourage or discourage membership in any labor organization...."

11 This general rule is based on a balancing of employee interests in engaging in concerted activities and employer interests in guaranteeing necessary production and discipline through control over work time and the work place. See Republic Aviation Corp. v. NLRB, 324 U.S. 793 (1945); NLRB v. United Aircraft Corp., 324 F.2d 128 (2d Cir. 1963), cert. denied, 376 U.S. 951 (1964). 
oped to prevent employers from impeding attempts to organize a previously unorganized plant, ${ }^{12}$ it undoubtedly also forbids unilaterally imposed rules aimed at preventing replacement or decertification of an existing representative. ${ }^{13}$ There is a conflict, however, between the Board and several of the circuit courts over whether unions are able to "waive" these restrictions on employer authority.

During the early part of the 1960's, the NLRB disapproved nosolicitation provisions except as applied to activities on behalf of incumbent unions. This policy was set forth in Gale Products, ${ }^{14}$ where the Board spoke of the importance of workplace communication to employee exercise of the right to choose bargaining representatives, ${ }^{15}$

Under certain special circumstances, the relative weights of the interests of the parties may be altered. For example, no-solicitation or no-distribution rules are allowed when employee solicitation or distribution would take place in nonworking areas that are nonetheless frequented by customers of the employer, notably sales areas of department stores. See, e.g., Famous-Barr Co., 59 N.L.R.B. 976, 15 L.R.R.M. 173 (1944), modified and enforced sub nom., NLRB v. May Dep't Stores, 154 F.2d 533 (8th Cir. 1946), cert. denied, 329 U.S. 725 (1946). Similarly an employer's interest in keeping outsiders off his premises has been found sufficient to permit him to enforce a rule broadly prohibiting solicitation and distribution on his premises by nonemployees, as long as alternative channels of communication are available. See, e.g., NLRB v. Babcock \& Wilcox Co., 351 U.S. 105 (1956). On the subject of employer no-solicitation rules generally, see Dereshinsky, The Solicitation and Distribution Rules of the NLRB, 40 U. CIN. L. REv. 417 (1971); Vanderheyden, Employee Solicitation and Distribution Rights: $A$ Second Look, 14 LAB. L.J. 781 (1963).

12 Similarly, an employer may not dominate a representative, NLRA $\$ 8$ (a)(2), 29 U.S.C. $\S 158(a)(2)$ (1970), nor favor one of two rivals. NLRA $\S 8(a)(3), 29$ U.S.C. $\$ 158$ (a)(3) (1970); NLRB v. Waterman S.S. Co., 309 U.S. 206 (1940); Majestic Molded Prods., Inc. v. NLRB, 330 F.2d 603 (2d Cir. 1964); NLRB v. Yale \& Towne Mfg. Co., 114 F.2d 376 (2d Cir. 1940).

13 Gf. General Ariline \& Film Corp., 145 N.L.R.B. 1215, 55 L.R.R.M. 1126 (1964); Gale Products Div., Outboard Marine Corp., 142 N.L.R.B. 1246, 1249, 53 L.R.R.M. 1242, 1243 (1963), enforcement denied, 337 F.2d 390 (7th Cir. 1964); Fruitvale Canning Co., 90 N.L.R.B. 884, 26 L.R.R.M. 1281 (1950).

14142 N.L.R.B. 1246, 53 L.R.R.M. 1242 (1963). The deposed president of the certified representative had circulated membership cards for an independent union. He was warned by his employer that he was in violation of collective bargaining contract provisions broadly prohibiting distribution and solicitation and would be discharged if he continued his activities. The Board found that promulgation of the provisions and the threat of discharge constituted unfair labor practices under section $8(a)(1)$ and struck down the rule except as applied to activities on behalf of the incumbent union. The Seventh Circuit denied enforcement, 337 F.2d 390 (7th Gir. 1964). See discussion of the Seventh Circuit's opinion in text and notes at notes 24-25 infra. The Board followed its Gale Products principle in a number of other cases، See, e.g., Armco Steel Corp., 183 N.L.R.B. No. 26, 74 L.R.R.M. 1599 (June 10, 1970); IAM (McDonnell Douglas Corp.), 171 N.L.R.B. 234, 68 L.R.R.M. 1051 (1968), modified and enforced, 415 F.2d 113 (8th Gir. 1969); Mid States Metal Prods. Inc., 156 N.I.R.B. 872, 61 L.R.R.M. 1159 (1966), enforced, 403 F.2d 702 (5th Cir. 1968); General Motors Corp., 147 N.L.R.B. 509, 56 L.R.R.M. 1241 (1964), enforcement denied, 345 F.2d 517 (6th Cir. 1965).

15142 N.L.R.B. at 1249, 53 L.R.R.M. at 1243. See also May Dep't Stores, 136 N.L.R.B. 797, 802, 49 L.R.R.M. 1862, 1864 (1962), enforcement denied, 316 F.2d 797 (6th Cir. 1963). 
and distinguished restrictions on solicitation for incumbent unions from similar restraints on solicitation for competing unions, approving only the former. In NLRB v. Mid-States Metal Products Co., ${ }^{16}$ the Fifth Circuit upheld a similar Board finding of a violation of section $8(a)(1)$ based on the discharge of an employee for circulating a decertification petition in violation of a contractual no-solicitation provision. In enforcing the Board's order, the court stated broadly that, although the right to engage in some forms of concerted activities can be waived by the bargaining representative, economic rights are distinguishable from the individual rights essential to proper selection and reevaluation of the collective bargaining representative. ${ }^{17}$ This distinction rested in part on the disparity of interest between unions and employees relative to employees' ability to oust their bargaining representative. ${ }^{18}$

The Board has recently adopted a modification of its Gale Products decision, following the Eighth Circuit's decision in IAM v. NLRB (McDonnell Douglas). ${ }^{19}$ In that case, the Board had invalidated a no-distribution provision as to all parties except the incumbent union;20 the circuit court, relying on Mid-States Metal Products, enforced the Board order, but only after modifying it to prohibit application of the provision to all union distributions, whether for or against the incumbent. ${ }^{21}$

The Sixth and Seventh Circuits have accepted neither the Board's former position of partial invalidation nor the Board's and Eighth Circuit's current position of total invalidation. Instead, they have relied on dicta from early Board decisions ${ }^{22}$ to support the principle that unions

10403 F.2d 702 (5th Cir. 1968), enforcing 156 N.L.R.B. 872, 61 L.R.R.M. 1159 (1966), noted in 20 Syracuse L. Rev. 796 (1969); 22 VAND. L. Rev. 664 (1969); 14 Vilt. L. Rev. 552 (1969).

17403 F.2d at 705.

$18 I d$.

19415 F.2d 113 (8th Cir. 1969), modifying and enforcing 171 N.L.R.B. 234, 68 L.R.R.M. 1051 (1968).

20415 F.2d at 116. The court reserved, however, the question of the validity of restrictions applicable only to periods when election or contract bars preclude filing a petition with the Board. Id. at 115-16. Although the employees' interest in campaigning during these periods is less than during other periods, it is still substantial. A campaign against an entrenched union necessitates activities well in advance of the filing of a petition.

21 The Board followed this approach in Magnavox Co., 195 N.L.R.B. 65 , 79 L.R.R.M. 1283 (1972). The trial examiner had applied the Board's Gale Products rule in finding that a broad no-distribution rule in which the union acquiesced was invalid when applied to distribution on behalf of any union other than the incumbent. Relying on McDonnell Douglas, the Board modified the order, declaring that the rule could not be applied to restrict activities on behalf of any union, including the incumbent. The Sixth Circuit denied enforcement, Magnavox Co. v. NLRB, 474 F.2d 1269 (1973), cert. granted, 42 L.W. 3174 (Oct. 9, 1973) relying on its decision in Armco, discussed in text at notes 26-30 infra.

22 Fruitvale Canning Co., 90 N.L.R.B. 884, 885, 26 L.R.R.M. 1281, 1281-82 (1950); Famous Barr Co., 59 N.L.R.B. 976, 981, 982 n.17, I5 L.L.R.M. 173, 174 (1944), modified 
are able to "waive" employee solicitation rights. ${ }^{23}$ For example, in $N L R B$ v. Gale Products Division of Outboard Marine Corp., ${ }^{24}$ the Seventh Circuit denied enforcement of the Board's finding of an 8(a)(1) violation, stressing that the no-distribution provision did not "strip the employees of fundamental rights guaranteed by the Act" but only precluded "a convenient-albeit a most effective-way of their exercise ... in favor of the available alternatives ...."25

In Armco Steel Corp. v. NLRB,,$^{26}$ the Sixth Circuit denied enforcement of a similar Board finding of a section $8(a)(1)$ violation. ${ }^{27}$ Freedom of contract, the court explained, is "one of the most important rights enjoyed by labor unions and employers." 28 The court compared the solicitation and distribution "waiver" to permissible waivers of other employee statutory rights, notably the right to strike. It expressed concern over the discriminatory effect of the Board's order (allowing enforcement of the provision only against the incumbent) and the Board's failure to consider the existence of alternative means of communication. Underlying the decision was the court's view that "[p]resumably the union obtained from Armco a quid pro quo for its assent to the clause." 29 The court concluded that "[t]he Board has no power to interfere with the exercise of that right or to sit in judgment on the wisdom of substantive contractual provisions."30

\section{B. The Bargaining Process and Contractually Imposed No-Solicitation Rules}

The proscription of unilaterally imposed no-solicitation rules has been considered warranted because the rules sacrificed crucial employee

and enforced sub nom., NLRB v. May Dep't Stores, 154 F.2d 533 (8th Cir.), cert. denied, 329 U.S. 725 (1946).

23 The District of Columbia Circuit Court has indirectly taken the same approach. See United Steelworkers v. NLRB, 377 F.2d 140 (D.C. Cir. 1966).

24337 F.2d 390 (7th Cir. 1964), noted in 44 NEB. L. REv. 645 (1965). The Board's decision in Gale Products is discussed in text and notes at notes 14-15 supra.

25337 F.2d at 392.

26344 F.2d 621 (6th Cir. 1965).

27 The Sixth Circuit has adhered to this position. See Magnavox Co. v. NLRB, 474 F.2d 1269 (6th Cir. 1973), cert. granted, 42 L.W. 3174 (Oct. 9, 1973), denying enforcement of 195 N.L.R.B. 265, 79 L.R.R.M. 1283 (1972); General Motors Corp. v. NLRB, 345 F.2d 516 (6th Cir. 1965), denying enforcement of 147 N.L.R.B. 509, 56 L.R.R.M. 1241 (1964). The District of Columbia Circuit has held that the NLRB could rely on the Sixth Circuit's decision in Armco when the relevant events occurred in that circuit and an identical provision was involved, see United Steelworkers v. NLRB, 377 F.2d 140 (D.C. Cir. 1966), but the Board has recently refused to follow Armco in such a situation. Armco Steel Corp., 183 N.L.R.B. No. 26, 74 L.R.R.M. 1599 (June 10, 1970).

28344 F.2d at 624.

29 Id. at 625 .

$30 \mathrm{Id}$, at 624 . 
interests to preserve relatively insignificant employer interests. ${ }^{31}$ Negotiated contract terms, however, might alter this balance enough to justify no-solicitation rules. Allowing waivers might benefit employees, at least to the extent that their representatives trade solicitation rights for employer concessions that are more valuable to the employees. If this view is adopted, the union might be seen as having discretion both to waive solicitation rights and to determine what concessions are sufficient to justify the waivers.

The determinative question is the scope of the bargaining representative's authority. If the representative, by making particular concessions or demands, acts in excess of his authority or in violation of his duty to represent unit employees fairly and equally, section $8(b)(1)(A)$ is violated. ${ }^{32}$ The employer is not required to bargain on such demands nor entitled to take benefit from such concessions, ${ }^{33}$ and if the employer does acquiesce, he should be found to be in violation of $8(a)(1)$ and $8(a)(3)$ to the extent he would have been if he had acted unilaterally. ${ }^{34}$

In allowing contractual waivers of solicitation rights, the Sixth and Seventh Circuits have stressed the generally recognized policy ${ }^{35}$ of encouraging private resolution of disputes between the employer and the union. Although the union's authority is limited to representation of employee interests, this policy allows union officers wide latitude in balancing employee interests against employer concessions in the give

31 See note 11 supra.

32 A union that does not fulfill its duty of fair representation violates sections $8(\mathrm{~b})(\mathrm{l})$ (A) and 8(b)(2) of the NLRA. Truck Drivers Local 568 v. NLRB, 379 F.2d 137 (D.C. Cir. 1967); Local 12, United Rubber Workers v. NLRB, 368 F.2d 12 (5th Cir. 1966), cert. denied, 389 U.S. 837 (1967); cf. Miranda Fuel Co., 140 N.L.R.B. 181, 51 L.R.R.M. 1584 (1962), enforcement denied, 326 F.2d 172 (2d Cir. 1963). See also Steele v. Louisville \& N.R.R., 323 U.S. 192 (1944).

33 Steele v. Louisville \& N.R.R., 323 U.S. 192, 203-04 (1944); Richardson v. Texas \& N.O.R.R., 242 F.2d 230, 236 (5th Cir. 1957); NLRB v. Bell Aircraft Corp., 206 F.2d 235, 237 (2d Cir. 1953). If the bargaining representative is empowered to request restrictions on unit employee solicitation rights, the employer not only may be permitted to accept the request, he also may be required to consider it because of his statutory duty to bargain with the representative relative to "wages, hours, and other terms and conditions of employment." NLRA §§ 8(a)(5), 8(d), 29 U.S.C. $\$ \S 158(a)(5), 158(d)$ (1970).

34 NLRB v. Bell Aircraft Corp., 206 F.2d 235, 237 (2d Cir. 1953); cf. Steele v. Louisville \& N.R.R., 323 U.S. 192 (1944); Richardson v. Texas \& N.O.R.R., 242 F.2d 230 (5th Cir. 1953). The cases dealing with contractually imposed no-solicitation rules have not treated as relevant whether the restraint of section 7 rights was charged against the employer under sections $8(a)(1)$ and $8(a)(3)$ or against the union under section $8(b)(1)(A)$. See text and notes at notes $22-30$ supra.

35 See United Steelworkers v. Warrior \& Gulf Nav. Co., 363 U.S. 574 (1960); United Steelworkers v. American Mfg. Co., 363 U.S. 564 (1960); Textile Workers v. Lincoln Mills, 353 U.S. 448, 454-55 (1957); LMRA \& 203(d), 29 U.S.C. \& 173(d) (1970). 
and take of negotiations. ${ }^{36}$ Bargaining for no-solicitation provisions that benefit most unit employees therefore might be within the scope of this authority. ${ }^{37}$

Although a policy favoring private resolution of bargaining disputes can properly be followed with respect to waivers of certain rights to engage in concerted activity, such as the right to strike, ${ }^{38}$ it seems inappropriate to apply the policy to union waivers of employee solicitation rights. Permitting the bargaining representative to waive employees' right to strike by negotiating a no-strike clause is logical given the nature of that right. First, the waiver of the right to strike seriously limits the power of the union as well as that of the employees, and the union has no incentive to abandon that right without receiving a substantial concession. Second, the NLRA's goal of promoting economic stability ${ }^{39}$ is directly and substantially furthered by recognition of the parties' right to agree to limitations on rights to strike and lock out and to nondisruptive means of dispute settlement. ${ }^{40}$

No-solicitation clauses do not have either of these positive attributes of no-strike clauses. First, in negotiations on a no-solicitation clause it is possible for the union to waive major employee rights without seriously prejudicing its own position; indeed, a no-solicitation clause, while weakening the rights of the individual employees, strengthens the position of the union. Second, the degree to which economic stability is promoted by restrictions on employees' freedom to solicit for decertification or replacement is much less significant than the stability provided by restrictions on their freedom to strike at any time.

36 See, e.g., Ford Motor Co. v. Huffman, 345 U.S. 330, 338 (1952).

37 Under this approach, the Board would defer to the bargaining representative's judgment in determining whether there had been a significant benefit to employees from the waiver and would avoid any nullification or redrafting of the contract that would alter the balance of benefits arrived at by the parties in their original agreement.

38 The right to strike may be waived. See United Steelworkers v. Warrior \& Gulf Nav. Co., 363 U.S. 574 (1960); Mastro Plastics Corp. v. NLRB, 350 U.S. 270 (1956).

39 See NLRA § 1, 29 U.S.C. $\$ 151$ (1970).

40 In assessing the scope of restrictions on the right to strike, courts frequently consider whether the collective agreement provides for resort to arbitration for the dispute involved. See, e.g., Local 174, Teamsters v. Lucas Flour Co., 369 U.S. 95, 106 (1962). This treatment is justified on the ground that industrial peace is promoted by the existence of such clauses and arbitration rights are a reasonable exchange for the loss of more coercive means of dispute settlement. See generally United Steelworkers v. Warrior \& Gulf Nav. Co., 363 U.S. 574, 578 (1960); Textile Workers v. Lincoln Mills, 353 U.S. 448, 454-55 (1957). But cf. Drake Bakeries v. Local 50, American Bakery Workers, 370 U.S. 254, $261 n .7$ (1962). The probability of a reasonable exchange and the amount of furtherance of industrial stability are both much smaller in the case of solicitation waivers. 


\section{Union Authority to Negotiate a Contractual Waiver of Solicitation Rights}

Because a majority of employees must authorize the bargaining representative to represent all the employees in the unit, it has frequently been suggested that the representative is an agent of the employees. ${ }^{41}$ Under agency principles, the representative might be authorized to waive employees' solicitation rights in exchange for benefits under a collective bargaining agreement. ${ }^{42}$ Agency, however, is an inadequate description of the relationship between the representative and many of the employees in the unit. Many employees may never have voted for the union in a representation election, executed an authorization card, joined the union, or otherwise shown initial consent to the representative's agency. Contrary to common law rules of agency, ${ }^{43}$ employees, whether consenting or nonconsenting, are not completely free to terminate the union's representation. ${ }^{44}$ Thus, although some employees must have consented to the representation, agency law does not provide an adequate justification or explanation of the representative's power.

Alternatively, the ability of a labor organization to negotiate with an employer may be viewed as a function of its economic strength. A strong employee organization will wish to define the terms of employment of nonconsenting employees as a means of establishing uniformity in working conditions and reducing divisive competition in its mem-

41 See, e.g., Marvel Scheblex Div., Borg Warner Corp., 56 N.L.R.B. 105, 108, 14 L.R.R.M. 111, 112 (1944); Mueller v. Chicago \& N.W. Ry. Co., 194 Minn. 83, 85, 259 N.W. 798, 799 (1935); Comment, Individual Rights in Industrial Self-Government: $A$ "State Action" Analysis, 63 Nw. U.L. REv. 4, 9 ff. (1968).

42 An agent generally has authority to contract on behalf of his principal. REsTATEMENT (SECOND) OF AGENCY $\S 144$ (1957). Thus, he can give up rights of the principal in exchange for contractual consideration. See, for example, the following cases dealing with the right of a bargaining representative to modify seniority rights: Ford Motor Co. v. Huffman, 345 U.S. 330 (1953); Oddie v. Ross Gear \&c Tool Co., 305 F.2d 143, 149-50 (6th Cir. 1962); Wagner Mfg., Inc. v. Culbertson, 206 N.E.2d 378 (Ind. App. 1965). Some cases, however, suggest limitations on the agent's right to modify a contract. See, e.g., Ferro Concrete Constr. Co. v. United States, 112 F.2d 488, 492 (Ist Cir. 1940); State Finance Co. v. Hershel Calif. Fruit Prods. Co., 8 Cal. App. 2d 524, 527-28, 47 P.2d 821, 823 (1935). But see Upshur County v. Heydrick, 221 S.W.2d 326, 329 (Tex. Civ. App. 1949).

43 Restatement (SeCOND) OF AGency \& 118 (1957).

44 American Seating Co., 106 N.L.R.B. 250, 252, 32 L.R.R.M. 1439, 1440-41 (1953). Acceptance or retention of employment should not be regarded as original or continuing consent to the agent's authority. The employee's mobility is severely curtailed by the information, transportation, training, and psychological costs associated with changing jobs. The Wagner Act's encouragement and protection of union activities reflects awareness of these costs. See NLRA § 1, 29 U.S.C. § 151 (1970). It would, therefore, be inconsistent with the public policy embodied in that Act to find contractual consent to labor union rules merely from job retention. 
bers' labor markets. Individuals or other groups of employees, however, will wish to make competing demands and offers, and it is not clear that a union could consistently command the power necessary to require the employer to bargain exclusively with that union. The provisions of the NLRA, however, guarantee exclusivity to majority unions and limit the right of other groups to bargain with or exercise economic power against the employer. ${ }^{45}$ Consequently, when the union acts to impose terms of employment on all members of the bargaining unit, including individuals who would not have supported the union, it should be viewed as exercising power derived from the NLRA. When this authority is exercised, particular attention should be paid to restrictions that the Act explicitly or implicitly imposes on union actions.

It is reasonable to conclude that Congress did not intend to authorize bargaining representatives to abridge freedom of communication among their constituencies. A major purpose of the NLRA and subsequent labor legislation was to provide employees power to influence their working conditions. If the legislation is to foster self-determination for employees, it must protect a free flow of information about the beliefs and activities of the bargaining representative and of opposing factions. ${ }^{46}$ Without such a flow of information, employee control over

45 Thus, for example, minorities may not negotiate separate bargaining agreements with the employer. See J.I. Case Co. v. NLRB, 321 U.S. 332 (1944); Virginian R.R. v. System Fed'n, 300 U.S. 515, 548 (1937). An individual who participates in a strike in defiance of the designated bargaining representative is not protected by the NLRA against employer reprisals. Plasti-Line, Inc. v. NLRB, 278 F.2d 482 (6th Cir. 1960); NLRB v. Draper Corp., 145 F.2d 199 (4th Cir. 1944).

46 Cf. Summers, Legal Limitations on Union Discipline, 64 HARv. L. REv. 1049, 1074 (1951). It has been suggested that there are constitutional limitations on the union's ability to restrict employees' freedom of speech. See, e.g., Note, 44 Neb. L. Rev. 645 (1965); cf. Comment, Individual Rights in Industrial Self-Government: A "State Action" Analysis, supra note 41 , at 8 . Governmental action might be found in bargaining agent activities on two grounds. See generally, Lewis, The Meaning of State Action, 60 Colum. L. Rrv. 1083 (1960); Wellington, The Constitution, the Labor Union and "Governmental Action," 70 YALE L.J. 345 (1961). First, state action is involved when Congress or a state legislature affirmatively enables a party to act in a manner adversely affecting interests of a third party. See Steele v. Louisville \& N.R.R., 323 U.S. 192 (1944). See also American Communication Ass'n v. Douds, 339 U.S. 382, 401-02 (1950). A finding of state action, however, would not necessarily lead to limitations on union power to waive employee solicitation rights. It might be argued that because the right to solicit and distribute on employer premises is generally treated as a statutory rather than a constitutional right, see, e.g., Central Fardware -Co. v. NLRB, 407 U.S. 539 (1972), Congress could delegate to the bargaining representative authority to restrict this right. It is not clear, therefore, that a finding of state action through affirmative grants of power precludes a bargaining representative from waiving employee solicitation rights.

The second ground on which state action might be found is the existence of a strong similarity or kinship between government and the labor organization. This similarity can 
representatives, and thus over working conditions, would be severely restricted.

The existence of alternative channels for communication of such information, emphasized by the Sixth Circuit in Armco, ${ }^{47}$ is irrelevant; the same detriment to the employee that led to the general proscription of employer-imposed no-solicitation rules without regard to the existence of alternative means of communication ${ }^{48}$ exists when contractual provisions are enforced.

In the absence of clear evidence that employee interests are served by rules restricting communication, employees should retain their right to distribute and solicit in the most appropriate forum, the place of work..$^{49}$ Actions of a bargaining representative that abridge this right should be held a violation of the representative's duty of fair representation and coercive of the employees' section 7 rights and, thus, a violation of section $8(\mathrm{~b})(1)(\mathrm{A}) .{ }^{50}$ Since the employer cannot rely on the bargaining representative's acquiescence to justify an otherwise prohibited restriction, ${ }^{51}$ any attempt by the employer to enforce such a clause should be held a violation of section $8(a)(1)$.

\section{INTRA-UNION DISCIPLINE FOR ATTEMPTS TO REMOVE BARgaINING REPRESENTATIVES ${ }^{52}$}

A union's power to restrict its members' activities, unlike its authority to negotiate bargaining agreement provisions affecting all unit employees, is not based on authority granted by federal labor legislation.

be found in the underlying assumption of the NLRA that the unit employee, unlike members of other organizations in our society, is not free to leave the unit and thus may become, in effect, an involuntary subject of the "legislating" union. It might be argued from this that an employee must be accorded a constitutional right to select those who will govern him. Nevertheless, although the Board and the courts have deemed the right to organize and select representatives a "fundamental" one under the Act, see UAW v. Wisconsin Employment Relations Bd., 336 U.S. 245, 259 (1949); NLRB v. Jones \& Laughlin Steel Corp., 301 U.S. 1, 33 (1937), it has never been accorded constitutional status.

47344 F.2d 621, 625 (1965).

48 See, e.g., Republic Aviation Corp. v. NLRB, 324 U.S. 793 (1945); Republic Aluminum Co. v. NLRB, 394 F.2d 405, 408 (5th Cir. 1968); cf. NLRB v. Babcock \& Wilcox Co., 351 U.S. 105, 112-13 (1956); General Aniline \& Film Corp., 145 N.L.R.B. 1215, 1219, 55 L.R.R.M. 1126, 1127 (1964).

49 That is, in situations where there are not special circumstances justifying an employer's unilateral restrictions on the rights. See note 11 supra.

so See note 32 supra.

51 See text and note at note 34 supra.

52 On problems posed by union discipline of its members, see generally Christensen, Union Discipline Under Federal Law: Institutional Dilemmas in an Industrial Democracy, 43 N.Y.U.L. REv. 227 (1968); Summers, supra note 46. 
Unions have historically been considered voluntary associations. ${ }^{53}$ They generally have been allowed to enforce even arbitrary conditions to restrict membership ${ }^{5 \pm}$ and to fine, suspend, or expel members by nondiscriminatory procedures provided in the union constitution or bylaws. ${ }^{55}$ The NLRA leaves this situation unchanged in most respects. Thus, although section $8(\mathrm{~b})(1)(\mathrm{A})$ prohibits the union from restraining employees' exercise of their rights, the section's proviso states: "this paragraph shall not impair the right of a labor organization to prescribe its own rules with respect to the acquisition or retention of membership therein." 56 The union's right to impose such discipline on its members is considered a term of a contract between the union and its members ${ }^{57}$ or among the members. ${ }^{58}$ Union constitutions or by-laws frequently provide that recalcitrant members may be fined, suspended, or expelled for strikebreaking, dual unionism, or "conduct unbecoming a union member"-such as seeking to replace the union with another bargaining representative. Union-imposed discipline is a powerful disincentive to union members' seeking to exercise their section 7 rights by decertifying or replacing the incumbent union.

Although the relevant sections of the NLRA and LMRDA make no explicit distinctions between expulsion, suspension, and fines, ${ }^{69}$ the courts have held that a union may punish decertification and replacement efforts by suspending or expelling, but not by fining, the dissident member. ${ }^{00}$ These decisions seem correct insofar as they forbid fines, but incorrect in allowing expulsion and overbroad in allowing

63 Frank v. National Alliance of Bill Posters, 89 N.J.L. 380, 381, 99 A. 134, 135 (Sup. Ct. 1916); Mayer v. Journeymen Stonecutters' Ass'n, 47 N.J. Eq. 519, 524, 20 A. 492, 494 (Ch. 1890). See generally, Summers, Right to Join a Union, 47 Colum. L. REv. 33 (1947). But see Civil Rights Act of 1964 (Equal Employment Opportunities) § 703(c), 42 U.S.C. § $2000(e)(2)(c)(1970)$.

54 See, e.g., Moynahan v. Pari-Mutuel Employees Guild, Local 280, 317 F.2d 203 (9th Cir.), cert. denied, 375 U.S. 911 (1963); Union Starch \& Refining Co. v. NLRB, 186 F.2d 1008 (7th Cir.), cert. denied, 342 U.S. 815 (1951). See also cases collected in Annot., 33 A.L.R.3d 1305, 1309-10 (1970).

б5 See, e.g., American Newspaper Publishers Ass'n v. NLRB, 193 F.2d 782, 800 (7th Cir. 1951), aff'd, 345 U.S. 100 (1953); Sawyers v. Grand Lodge, IAM, 279 F. Supp. 747, 755-56 (E.D. Mo. 1967); Davis v. International Alliance of Theatrical Stage Employees, 60 Cal. App. 2d 713, 141 P.2d 486 (1943).

56 NLRA § 8(b)(I)(A), 29 U.S.C. § $158(\mathrm{~b})(1)(\mathrm{A})(1970)$.

57 See, e.g., NLRB v. Allis-Chalmers Mfg. Co., 388 U.S. 175, 182 (1967); IAM v. Gonzales, 356 U.S. 617, 618-19 (1958).

58 See, e.g., Elfer v. Marine Eng'rs Beneficial Ass'n No. 12, 179 La. 383, 392, 154 So. 32 , 35 (1934); State ex rel. Dame v. LeFevre, 251 Wis. 146, 152, 28 N.W.2d 349, 353 (1947). See generally Cox, The Role of Law in Preserving Union Democracy, 72 HARv. L. REv. $609,613(1959)$.

69 Cf. LMRDA § 101(a)(5), 29 U.S.C. § 411(a)(5) (1970).

60 See text at notes 63-92 infra. 
suspension for all decertification activities. A careful weighing of the union and employee interests involved, in light of the justifications offered by the courts for suspension and expulsion, suggests that the only permissible response should be suspension from the time a decertification or election petition is filed until the end of the campaign.

\section{A. Fines}

The Supreme Court has held that fines may be used to enforce a union rule that is "properly adopted ... [ and] reflects a legitimate union interest, impairs no policy Congress has imbedded in the labor laws, and is reasonably enforced against union members who are free to leave the union and escape the rule." 61 The Court has also held that the Board is not authorized to inquire into the reasonableness of the amount of otherwise valid fines. ${ }^{62}$

The use of fines to restrain access of members to Board processes, however, has been held an unfair labor practice. For example, in Charles $S$. Skura, ${ }^{63}$ the NLRB found that a union had violated section $8(\mathrm{~b})(\mathrm{I})(\mathrm{A})$ by imposing a fine on a member who had filed an unfair labor practice charge against the union. The Board pointed out that effective administration of the NLRA requires filing of unfair labor practice charges by individuals because the General Counsel is unable to initiate such an action. ${ }^{64}$ The Board then stated: "Considering the overriding public interest involved, ... a rule ... by means of which a union seeks to prevent or limit access to the Board's processes is beyond the lawful competency of a labor organization to enforce by coercive means."65 In NLRB v. International Molders and Allied Workers

61 Scofield v. NLRB, 394 U.S. 423,490 (1969); see NLRB v. Allis-Chalmers Mfg. Co., 388 U.S. 175 (1967). See also Lodge 405, IAM v. NLRB, 412 U.S. 84 (1973); NLRB v. Local 1029, Textile Workers, 409 U.S. 213 (1973).

In the case of a union shop, the Supreme Court has reserved decision on whether fines may be enforced against members who have expressed their intention to be treated as members of the union only for purposes of dues payment. See NLRB v. Allis-Chalmers Mfg. Co., 388 U.S. 175, 196-97 (1967). With reference to fines, the term "union members" as used herein excludes "dues only" members.

62 NLRB v. Boeing Co., 412 U.S. 67 (1973).

63 148 N.L.R.B. 679, 57 L.R.R.M. 1009 (1964). See also Laborers Union (Arnold Constr. Co.), 201 N.L.R.B. No. 24, 82 L.R.R.M. 1257 (Jan. 16, 1973); Lathers' Union, Local 238, 156 N.L.R.B. 997, 61 L.R.R.M. 1172 (1966); H.B. Roberts, 148 N.L.R.B. 674, 57 L.R.R.M. 1012 (1964), modified and enforced, 350 F.2d 427 (D.C. Cir. 1965).

04148 N.L.R.B. at 681, 57 L.R.R.M. at 1011 (1964). This same factor was emphasized by the Supreme Court in NLRB v. Marine Workers, 391 U.S. 418, 424 (1968), discussed in text and notes at notes 76-80 infra.

65148 N.L.R.B. at 682, 57 L.R.R.M. at 1010-11; cf. LMRDA § 101(a)(4), 29 U.S.C. § 411(a)(4) (1970). 
Local 125 (Blackhawk Tanning), ${ }^{60}$ the Seventh Circuit adopted the same approach. Apparently untroubled by possible inconsistency with its earlier approval of contractual waivers of employee solicitation rights, including the circulation of decertification petitions, ${ }^{b 7}$ the court enforced a Board finding that the union had violated section $8(\mathrm{~b})(1)(\mathrm{A})$ by fining a union member for circulating a decertification petition. ${ }^{68}$ The court stressed that employees must have a right of access to the Board's processes without impediments by private organizations. ${ }^{69}$ When this right conflicts with union interests, "section $8(b)(1)(A)$ and its proviso envision a balancing of the rights of the union against the rights of employees and members on a case by case basis." 70 The court then stated that a decertification petition, unlike an unfair labor practice charge, "attacks the very existence of the union as exclusive bargaining agent," 71 thus justifying defensive action by the union. Fines, however, were not seen as serving these defensive purposes: "Once a member pays the fine, he retains his membership and is able to attend meetings and learn of union strategy .... [The fine's] only effect is to punish a member who wishes to oust the union ...."72

In Local 702, IAM v. Loudermilk, ${ }^{73}$ the Fifth Circuit held that the imposition of a fine on a union member for joining and supporting another union infringed the free speech rights guaranteed him under section 101(a)(2) of the LMRDA.74 In reaching this conclusion the court applied a balancing test, similar to that used in Blackhawk Tanning, to the proviso of section 101(a)(2) which states: "nothing herein shall be construed to impair the right of a labor organization to adopt

66442 F.2d 92 (7th Cir. 1971), enforcing 178 N.L.R.B. 208, 72 L.R.R.M. 1049 (1969).

67 See text and notes at notes 24-25 supra. The contractual waiver imposes a greater limitation on the ability to replace the representative because it restricts both union and nonunion members. On the other hand, the Seventh Circuit's positions may be consistent if concessions possibly received by the contracting union are emphasized.

68 The Board has also invoked the Blackhawk Tanning rule where a union member was fined for soliciting authorization cards that a rival of the incumbent intended to use to seek an election. Tri-Rivers Marine Eng'rs (U.S. Steel Corp.), 189 N.L.R.B. 838, 77 L.R.R.M. 1027 (1971).

60442 F.2d at 94.

$70 \mathrm{Id}$.

71 Id. The court's dicta approved the use of expulsion. Id.

72 Id. The Board relied upon this distinction in Tri-Rivers Marine Eng'rs (U.S. Steel Corp.), 189 N.L.R.B. 838, 77 L.R.R.M. 1027 (1971).

73444 F.2d 719 (5th Cir. 1971).

7429 U.S.C. $\S 411$ (a)(2) (1970) provides in part: "Every member of any labor organization shall have the right to meet and assemble freely with other members; and to express any views, arguments, or opinions ...." The court noted that this section, added to the LMRDA on the floor of Congress, lacked an "informative legislative history." 444 F.2d at 721 . 
and enforce reasonable rules as to the responsibility of every member toward the organization as an institution. ..."75

In conclusion, the Board and the courts have found the imposition of fines as punishment for support of a rival union or decertification efforts to be a violation of the NLRA and the LMRDA because the infringement of employee rights caused by fines is not outweighed by any legitimate union interest in imposing the fine.

\section{B. Expulsion}

In NLRB v. Industrial Union of Marine Workers ${ }^{76}$ the Supreme Court restricted the right of unions to expel members for filing unfair labor practice charges with the Board before exhausting internal union remedies. The Court enforced the Board's order that the expelled member be restored to membership, ${ }^{77}$ emphasizing that "overriding public interest makes unimpeded access to the Board the only healthy alternative, except and unless plainly internal affairs of the union are involved."78 The Court explained: "[T] he proviso in Section $8(\mathrm{~b})(\mathrm{l})(\mathrm{A})$ that unions may design their own rules respecting 'the acquisition or retention of membership' is not so broad as to give the union power to penalize a member who invokes the protection of the Act for a matter that is in the public domain and beyond the internal affairs of the union." 79 In light of this prohibition of suspension and expulsion as a means of penalizing union members for resorting to Board processes and the Seventh Circuit's prohibition of fines as a means of punishing union members who seek to oust the incumbent union, ${ }^{80}$ it might be expected that a union would have no right to expel or suspend a member for activities intended to secure the removal of the union as unit bargaining representative. The Board and the courts, however, have refused to prohibit suspensions or expulsion for such activities.

75 LMRDA § 101(a)(2), 29 U.S.C. 411 (a)(2) (1970).

76391 U.S. 418 (1968).

77 The Board's decision is reported at 159 N.L.R.B. 1065, 62 L.R.R.M. 1301 (1966). See Cannery Workers' Union (Van Camp Sea Food Co.), 159 N.L.R.B. 843, 62 L.R.R.M. 1298 (1966), reaching the same result.

78391 U.S. at 424 . The involvement of the employer in the action underlying the charge in Marine Workers may have been a significant factor in the determination that internal union procedures could not be relied on for a complete remedy. Id. at 425. See also Laborer's Union (Arnold Constr. Co.), 201 N.L.R.B. No. 24, 82 L.R.R.M. 1257 (Jan. 16, 1973). Both Marine Workers and Skura involved conduct that might have violated both sections $8(\mathrm{~b})(2)$ and $8(\mathrm{a})(3)$.

79391 U.S. at 425 . The Court also held that section 101(a)(4), 29 U.S.C. \& 411(a)(4) (1970), did not require that internal union procedures be exhausted. Id. at 426 .

80 NLRB v. Molder's Local 125 (Blackhawk Tanning), 442 F.2d 92 (7th Cir. 1971). 
In Tawas Tube Products, ${ }^{81}$ objections to a decertification election were based on the expulsion of two employees from the union for actively supporting a decertification movement. The Board pointed out that "even a narrow reading of the [section $8(\mathrm{~b})(\mathrm{l})(\mathrm{A})$ ] proviso would necessarily allow a union to expel members who attack the very existence of the union as an institution," 82 and upheld the results of the election. The Board concluded: "It would be difficult for the Union to carry on an election campaign were [dissident members] entitled to 'equal rights and privileges . . . to attend membership meetings, and to participate in the deliberations and voting upon the business of such meetings . . . rights now guaranteed to union members by Section 101(a)(1) of the Labor-Management Reporting and Disclosure Act."83 The Board stated that a member's opposition to the union reflects a lack of concern over continued membership in the union. Skura was distinguished on the ground that the actions involved in that case were designed only to make the union abide by the Act; the dissident member had not threatened the union's very existence. ${ }^{84}$ Because the Board applies more stringent standards in determining whether an election was conducted under requisite laboratory conditions than it applies to the determination of whether conduct violates section $8,{ }^{85}$ the holding in Tawas Tube clearly indicates that the Board would not consider such an expulsion a violation of section $8(\mathrm{~b})(1)(\mathrm{A})$.

In Price v. $N L R B^{86}$ the Ninth Circuit, relying on Tawas Tube and distinguishing Skura, upheld the Board's dismissal of an unfair labor practice complaint based on $8(b)(1)(A)$, made by a member who had been suspended from membership for filing a decertification petition. The court stressed that the member's action had been "in a very real sense an attack on the very existence of the union"s7 and held that the union's action was protected by the proviso to $8(\mathrm{~b})(\mathrm{I})(\mathrm{A})$.

The basis for treating fines differently from suspension or expulsion may in part be found in the different weights accorded the forms of discipline in the Blackhawk Tanning balancing test. ${ }^{88}$ In that case the Seventh Gircuit attempted to distinguish the sanctions by finding that

81151 N.L.R.B. 46,58 L.R.R.M. 1330 (1965).

82 Id. at 48,58 L.R.R.M. at 1391 .

83 Id.

84 Id.

85 See, e.g., Dal-Tex Optical Co., 137 N.L.R.B. 1782, 50 L.R.R.M. 1152 (1962); General Shoe Corp., 77 N.I.R.B. 124, 21 L.R.R.M. 1337 (1948)

88373 F.2d 443 (9th Cir. 1967), enforcing 154 N.L.R.B. 692, 60 L.R.R.M. 1008 (1965).

87373 F.2d at 447.

88 See téxt at nơte 70 supra. 
fines were neither necessary nor effective in protecting the union as an institution. ${ }^{89}$ Suspension and expulsion-characterized by the Board in Tawas Tube as "defensive" measures-were, however, seen as both effective and appropriate. The Board in Tawas Tube $e^{80}$ and the Ninth Circuit in Price ${ }^{01}$ had stressed this point, saying that in an election contest between the incumbent and the union favored by the dissident member, the incumbent's status as bargaining representative would be endangered were it forced to keep an insurgent in its midst. Suspension or expulsion, according to this view, effectively removes a member who might pose a substantial threat to the continued viability of the union as bargaining representative.

A balancing is necessary between the interests of the union in meeting its responsibilities and preserving its institutional status ${ }^{92}$ and the interests of the member in continued membership. In setting up the interests to be balanced, however, the Board and the courts have failed to set forth accurately the interests of the employee in retaining membership, the differing union interests in the contexts of the circulation of a decertification petition and an election campaign, and the different effects of expulsion and suspension on the employee and the union.

It has frequently been asserted that an employee's opposition to the incumbent union indicates that he has no significant interest in retaining union membership; ${ }^{93}$ this is simply incorrect. First, although expulsion or suspension for opposition to the union should have no direct

89 Fines, like suspension or expulsion, have been found to be inherently coercive within the meaning of section 8(b)(1)(A). See NLRB v. Molder's Local 125, 442 F.2d 92, 94 (7th Cir. 1971). Since they are coercive, it is clear that they have some effect in protecting the union against active opposition. Thus, the distinction between fines and suspension or expulsion drawn in Blackhawk Tanning and other cases implies that deterrence per se is not a "Iegitimate" union interest. A valid defensive measure is evidently one that protects the union by preventing disruption of its processes or frustration of its efforts to communicate with unit employees, not merely one that protects its position.

90151 N.L.R.B. 46, 48, 58 L.R.R.M. 1330, 1331 (1965).

91378 F.2d 443, 447 (9th Cir. 1967). See discussion in text at notes 86-87 supra.

92 Protection of institutional status is probably a necessary element in this balance because of the provisos to sections $8(\mathrm{~b})(1)(A)$ and $101(\mathrm{a})(2)$. The Supreme Court has pointed out that section $8(\mathrm{~b})(\mathrm{I})(\mathrm{A})$, even without considering its proviso, "was not meant to regulate the internal affairs of unions," NLRB v. Allis-Chalmers Mfg. Co., 388 U.S. 175, 186 (1967). Certainly, its proviso prevents any inference that restrictions on the union's application of "reasonable" conditions of membership was intended. In interpreting this proviso, words subsequently used by Congress in passing the related proviso to LMRDA $\$ 101(a)(2)$ are relevant. For example, the similarity of the balancing tests in Blackhawk Tanning, see text at note 70 supra, and IAM v. Loudermilk, see text at notes 73-75 supra, indicates that these provisions are read in pari materia. Cf. NLRB v. Allis-Chalmers Mfg. Co., 388 U.S. 175, 194 (1967); NLRB v. Teamsters Local 639, 362 U.S. 274, 291-92 (1960).

93 See, e.g., Tawas Tube Prods., Inc., 151 N.L.R.B. 46, 49, 58 L.R.R.M. 1390, 1391 (1965). 
effect on the employee's job,94 practice may not match theory; even where the employer intends to obey the dictates of section $8(a)(3)$, the employee may not be aware of those protections. In addition, the dissident may have other economic interests in retaining membership, such as union strike benefits or pension plan coverage. ${ }^{95}$ The employee participating in decertification or replacement activities also may recognize the possibility of and wish protection against a failure of this particular means of control of his leadership. He may, therefore, desire to retain a voice in "internal" union decisions that will profoundly affect his interests. ${ }^{96}$ Expulsion or suspension deprives him of the opportunity to participate in this form of control over his working environment. ${ }^{97}$

The basic ground for approving suspension and expulsion has been that they are "valid defensive measures" because they prevent the member from either disrupting meetings or disclosing strategy. ${ }^{98}$ The union's need for these defenses, however, is questionable. Section 101(a)(2) of the LMRDA ${ }^{99}$ expressly protects the right of a union to control disruption of meetings regardless of the reason for the disruption. It is doubtful that meetings of a union seeking to protect its incumbency involve discussion of strategy that must be kept secret from rivals. Deterring opposition is not a valid union interest because it conflicts with NLRA policies of self-determination. ${ }^{100}$ Moreover, although the union may feel threatened by a solicitation of opposition whenever it occurs, it is only when support is strong and an election imminent that the threat is serious. Solicitation of opposition is a necessary aspect of pre-election campaigning, but often its only effect is to test support for a dissident faction and alert union leadership to a need for a change in their policies. The powerful defensive tool of barring a member from union activities should not be allowed unless an election is potentially imminent. Specifically, use of the tool should be allowed only within a limited time, for example sixty days, before the date when a petition for decertification or replacement may be filed. ${ }^{101}$

94 See NLRA \& 8(a)(3), 29 U.S.C. § 158(a)(3) (1970).

95 Cf. Cannery Workers' Union (Van Camp Sea Food Co.), 159 N.L.R.B. 843, 846, 62 L.R.R.M. 1298, 1299 (1966); Mitchell v. IAM, 196 Cal. App. 2d 796, 799, 16 Cal. Rptr. 813, 815 (1961); Spayd v. Ringing Rock Lodge, 270 Pa. 67, 113 A. 70 (1921).

${ }_{96}$ These decisions may include selection of officers to represent the unit, strike votes, and approval of contracts.

87 Cf. Summers, supra note 46 , at 1056-58.

98 See, e.g., Price v. NLRB, 373 F.2d 443, 447 (9th Cir. 1967); Tawas Tube Prods., Inc., 151 N.L.R.B. 46, 48, 58 L.R.R.M. 1330, 1331 (1965). On the role of deterrence, see note 89 supra.

9929 U.S.C. \& 411 (a)(2) (1970).

100 See text and notes at notes 11-12 and note 89 supra.

101 The date on which barring a member becomes justified must be prior to the filing 
More important, expulsion, as opposed to temporary suspension, cannot be regarded as a necessary defensive measure even during this period. Assuming that possible disclosure of incumbent election strategy by dissident members weakens the incumbent's ability to protect itself, the dangers of disclosure continue only until the election is held. Similarly, the problem of disruption of meetings (insofar as 101(a)(2) of the LMRDA does not offer a solution) relates to dissident tactics primarily used during the petition and campaign periods. It is not clear that a supporter of a rival union will necessarily be capable of, or interested in, sabotaging incumbent operations when replacement or decertification is not available.

Most of the time, elections are not imminent and, indeed, not permitted. The NLRA prohibits new elections within a year of preceding elections. ${ }^{102}$ Board policy imposes longer restrictions when valid collective bargaining agreements exist. ${ }^{103}$ Moreover, election campaigns take time and energy. An individual who opposed the union in an unsuccessful election drive may realize the futility of his position, and reconcile himself to working for his objectives through intra-union channels.

The legitimate interests that the union seeks to protect by suspension or expulsion could adequately be protected by denying an insurgent the right to participate in union activities until after the election is held. ${ }^{104}$ Pension and other economic rights of the suspended member could be frozen at pre-suspension levels until his automatic reinstatement, and dues payments would be suspended. ${ }^{105}$ This sanction would allow the union to protect its right to conduct its business with

of a petition because extensive campaigning must be conducted before this time. See note 4 supra. Petitions may be filed during a thirty day period beginning ninety days before the termination of an existing contract (of up to three years) and ending sixty days before the termination date. Leonard Wholesale Meats Co., 136 N.L.R.B. 1000, 41 L.R.R.M. 1901 (1962). When the contract bar is inapplicable, petitions may be filed at any time after sixty days preceding the first anniversary date of the last election. Randolph Metal Works, Inc., 147 N.L.R.B. 973, 56 L.R.R.M. 1348 (1964).

102 NLRA \& 9(c)(3), 29 U.S.C. \& 159(c)(3) (1970).

103 In practice, the bar will frequently extend for three years from the time of execution of a collective bargaining agreement. See, e.g., General Gable Corp., 139 N.L.R.B. 1123, 51 L.R.R.M. I 444 (1962).

104 Although relatively little campaigning is likely to take place after the election is conducted, rancor and hostility toward dissidents may be quite strong for a period following the election. Potential violence and general disruption of union activities, when balanced against the limited value the employee would realize from readmission to a hostile union, might justify permitting the suspension to continue for a limited period following the election.

105 Cf. Steelworkers Local 4186 (McGraw Edison Co.), 181 N.L.R.B. 992, 73 L.R.R.M. $1570(1970)$. 
minimal harassment, but would not subject the employee to the excessive penalties of expulsion. ${ }^{106}$ Limiting permissible union reaction to suspension would thus achieve the proper balance of union and employee interests. ${ }^{107}$

\section{ConGLUSION}

A central policy of the NLRA is the promotion of employees' right to choose their bargaining representative. The power to decertify or replace their bargaining representative is necessary for adequate exercise of that right. Accordingly, incumbent unions should not be allowed to curtail employee solicitation and distribution activities by agreeing to contractually imposed no-solicitation rules that would be invalid if imposed by the employer unilaterally. Similarly, incumbent unions should not be allowed to fine or expel members who have solicited opposition. The valid union interest in preserving its integrity so that it may continue to function as a bargaining representative is adequately protected if it is allowed to suspend, prior to a possible election, those dissident members who seek decertification or replacement.

John Anthony Strain

106 The protection thus afforded the employee is obviously not absolute. The union may still expel him for certain antiunion activities other than decertification and replacement efforts. For example, he might be expelled for attempting to hinder union performance of legal or contractual obligations, supporting the employer in a manner injurious to the union's effectiveness, or refusing to comply with valid union work rules or work stoppage decisions.

107 Cf. Note, 8 DuQUESNE L. REv. 432 (1970). 